\title{
Accountability, Counter-Terrorism and Civil Liberties
}

\author{
Jessie Blackbourn
}

\section{Introduction}

When the Conservative-led Coalition government was elected in 2010, it was at a time when terrorism had started to decline, both domestically and on a global level. In the UK, only one person ${ }^{1}$ had been killed as a result of international terrorism since the 2005 London attacks. ${ }^{2}$ Globally, after a sharp rise in the mid-2000s, by 2008, the number of terrorist incidents and deaths caused by terrorism had begun to level out. ${ }^{3}$ And in 2009, the UK's armed forces had withdrawn from military operations in Iraq. At the same time, the Coalition's Programme for Government included a proposal to 'reverse the substantial erosion of civil liberties and roll back state intrusion'. ${ }^{4}$ It was in these particular circumstances, that on entering office, the then Home Secretary, Theresa May initiated an internal review of the UK's counter-terrorism and security powers. The purpose of the review was to 'look at the issues of security and civil liberties in relation to the most sensitive and controversial counter-terrorism and security powers and, consistent with protecting the public and where possible, to provide a correction in favour of liberty. ${ }^{5}$ The review did indeed lead to the repeal of some of those controversial powers, including control orders, ${ }^{6}$ stop and search, ${ }^{7}$ and the 28 day period of extended precharge detention for terrorist suspects. ${ }^{8}$ The extent to which it actually provided a correction in favour of liberty is somewhat less clear. Control Orders were repealed, but immediately replaced with the only slightly less stringent TPIMs - Terrorism Prevention and Investigation Measures. ${ }^{9}$ The controversial stop and search powers in section 44 of the Terrorism Act 2000 were repealed, but only after the European Court of Human Rights found that they breached the right to respect for private life in Article 8 of the European Convention on Human Rights (ECHR). ${ }^{10}$ The maximum period of extended pre-charge detention was reduced from 28 days to 14, albeit the government also laid a Draft Detention of Terrorist Suspects (Temporary Extension) Bill before Parliament, the effect of which would be to extend the maximum period of pre-charge detention from 14 to 28 days in an emergency. ${ }^{11}$

This period of security 'liberalisation' 12 was relatively short-lived. The emergence of Islamic State as a global terrorist organisation in 2014 led to an increase in terrorist violence, both in Syria and Iraq, where the organisation declared its Caliphate, but also in Western countries, including the UK, perpetrated by 'foreign terrorist fighters'. The Coalition government's response was a refocusing of counter-terrorism towards security, and the introduction of new laws to facilitate a range of rights restrictive measures, including citizenship stripping ${ }^{13}$ and

\footnotetext{
${ }^{1}$ One of the perpetrators of the attempted bombing of Glasgow Airport in 2008 died during the attack. Haroon Siddique, 'Glasgow airport car bomber jailed for 32 years' The Guardian (17 December 2008).

${ }^{2}$ In the same time period, more than 20 persons were killed as a result of the conflict in Northern Ireland. 'Draft List of Deaths Related to the Conflict from 2002 to the present', CAIN <http://www.cain.ulst.ac.uk/issues/violence/deathsfrom2002draft.htm> accessed 15 March 2018.

3 Max Roser, Mohamed Nagdy and Hannah Ritchie, 'Terrorism', Our World in Data (January 2018) $<$ https://ourworldindata.org/terrorism> accessed 15 March 2018.

${ }^{4}$ HM Government, Review of Counter-Terrorism and Security Powers $(\mathrm{Cm} 8004,2011) 4$.

${ }^{5}$ Ibid.

${ }^{6}$ Terrorism Prevention and Investigation Measures Act 2011 s 1.

${ }^{7}$ Protection of Freedoms Act 2012 s 59.

${ }^{8}$ Ibid.

${ }^{9}$ See David Anderson, Terrorism Prevention and Investigation Measures in 2012 (2013) 4.

${ }^{10}$ Gillan and Quinton v UK (2010) 50 EHRR 45.

${ }^{11}$ HM Government, Draft Detention of Terrorist Suspects (Temporary Extension) Bills (Cm 8018, 2011).

${ }^{12}$ HM Government, The Coalition: Our Programme for Government (20 May 2010) 24.

${ }^{13}$ Immigration Act 2014 s 66.
} 
restrictions on movement both into and out of, ${ }^{14}$ as well as within, ${ }^{15}$ the UK. This is not entirely unsurprising, as May highlighted in the forward to the Review of Counter-Terrorism and Security Powers: 'national security is the primary duty of Government. ${ }^{16}$ However, it is a concern for civil liberties if the government is unrestrained in its counter-terrorism law making capabilities. In 1990, writing about the Thatcher government, Ewing and Gearty noted that 'The lack of any real constraints on the executive branch has led to a crisis of overgovernability, in which executive proposals quickly become law via a quiescent Parliament without sufficient consultation, scrutiny, or debate, and without any possibility of subsequent judicial challenge. ${ }^{17}$ This position has changed, particularly over the past two decades; the exceptional nature of counter-terrorism now requires more than just parliamentary oversight on enactment followed by subsequent judicial scrutiny. This is evidenced by the range of accountability institutions which have been established to provide oversight and review of counter-terrorism activities. Yet not all accounts of accountability are overwhelmingly positive. Frances Webber has argued that

the current Conservative government is changing the meaning of accountability. It is increasingly treating compliance with international legal norms and human rights as optional. It is systematically attacking the mechanisms of legal accountability, through legal aid cuts, removal of appeals, hiking court fees and even by vilifying human rights lawyers.' ${ }^{18}$

This article focuses on political, rather than legal, accountability. It evaluates the Coalition and Conservative governments' approach to oversight and review to protect civil liberties through the lens of counter-terrorism. The first question is whether this is a viable evaluation. It is not obvious that accountability mechanisms must necessarily provide a review in terms of civil liberties. The exception is the Joint Committee on Human Rights (JCHR). Its remit includes scrutinising 'the UK's compliance with its human rights obligations contained in a range of international treaties. ${ }^{19}$ It may also 'conduct thematic inquiries, where the Committee choose its own subjects of inquiry and seek evidence from a wide range of groups and individuals with relevant experience and interest. ${ }^{20}$ The JCHR has made use of this option to conduct numerous reviews of counter-terrorism laws, including on prosecution and pre-charge detention, and control orders. However, not all accountability institutions include scrutiny of the civil liberties aspects of counter-terrorism within their official mandate. The terms of reference for the Independent Reviewer of Terrorism Legislation - the UK office dedicated to post-enactment review of counter-terrorism laws - for example, only requires review of the operation of the laws. ${ }^{21}$ In effect then, the Independent Reviewer must merely report on how the laws have been used in any given year. Lord Carlile, who was appointed to the position in 2001, worked within this remit. In his first report on the Terrorism Act 2000, he stated: 'I have taken it as a basic tenet, not open to question as part of this reviewing process, that specific anti-terrorism legislation is necessary as an adjunct to and strengthening of the ordinary criminal law'. ${ }^{22}$ His

\footnotetext{
${ }^{14}$ Counter-Terrorism and Security Act 2015 pt 1.

${ }^{15}$ Ibid s 16.

${ }^{16}$ HM Government, Review of Counter-Terrorism and Security Powers (Cm 8004, 2011) 3.

${ }^{17}$ KD Ewing and CA Gearty, Freedom under Thatcher Civil Liberties in Modern Britain (OUP 1990) 6-7.

${ }^{18}$ Frances Webber, 'The Inversion of Accountability' (2016) 58(2) Race and Class 55, 56.

19 Joint Committee on Human Rights, 'Role' <http://www.parliament.uk/business/committees/committees-az/joint-select/human-rights-committee/role/> accessed 16 March 2018.

${ }^{20}$ Ibid.

${ }^{21}$ HL Deb 8 March 1984, vol 449, cols 405-406.

${ }^{22}$ Lord Carlile, Report on the Operation in 2001 of the Terrorism Act 2000 (2002) 5. He has been much criticised for this narrow approach. See: Inayat Bunglawala, 'Carlile's curious reasoning', The Guardian, 18 December 2007; Paul Lewis, 'Lord Carlile's 'credibility' as terror watchdog questioned by MP', The Guardian, 3 February
} 
successors have taken a more expansive approach. For example, in his first report on the Terrorism Acts, David Anderson, who was Independent Reviewer from 2011 to 2017, stated: 'Any assessment of whether they are necessary and proportionate in their operation must be conducted with an eye both to the current nature and extent of the terrorist threat in the United Kingdom, and to the range of tools available to the counterterrorism effort' ${ }^{23}$ This incorporated a test of proportionality and necessity to the review process. Anderson has also stated that he has evaluated whether the measures are 'effective' and 'fair'. ${ }^{24}$ This dovetails with what the Home Office perceives to be the remit of the Independent Reviewer, which it has recently described as being to 'monitor UK counter-terrorism legislation for its fairness, effectiveness and proportionality. ${ }^{25}$ Anderson has been explicit about the role of the office in scrutinising counter-terrorism in terms of civil liberties. He has stated that the purpose of review is 'to inform - so far as is possible within the necessary constraints of secrecy - the parliamentary and public debate over anti-terrorism powers and civil liberties in the UK.' ${ }^{26}$

Accountability institutions then do not have to, but often do, use civil liberties as a measure against which to review counter-terrorism in the UK. This is in line with the academic literature on accountability mechanisms. David Feldman has stated that scrutiny is a 'principled activity. Even if conducted in a somewhat unconstructive way, it has its own disciplines. The scrutineer tests the provisions of a measure against certain standards which are independent of the terms or subject matter of the measure itself, and can and should be applied consistently to all measures which are scrutinised. ${ }^{27}$ Similarly, Adam Tomkins has suggested that accountability mechanisms should be evaluated by assessing their efficacy as tools for promoting values. ${ }^{28}$ Mark Elliott agrees, he states that there is, 'an array of criteria or standards, by reference to which the object of the inquiry may be evaluated'. ${ }^{29}$ These include: legal criteria, principles of good administration, fundamental rights, political questions (such as whether a particular measure is wise, prudent, or in the public interest), and bureaucratic standards (for example, whether a measures offers value for money, is fit for purpose, and meets standards set). ${ }^{30}$

This article evaluates the Coalition and Conservative governments' approach to civil liberties since 2010 through the lens of counter-terrorism review. It highlights three major trends in their approach: a diminished parliamentary scrutiny, evidenced through the use of sunset clauses and government response to parliamentary committees; the establishment or revision of key accountability institutions, including the Independent Reviewer of Terrorism Legislation, Independent Privacy and Civil Liberties Board, and Counter-Extremism Commission; and the use of mechanisms to provide independent 'assurance' of internal reviews, such as that conducted by Lord Macdonald of Riverglaven into the Home Office's Review of CounterTerrorism and Security Powers, and David Anderson's recent oversight of the police and

2010; Andrew Lynch and Nicola McGarrity, 'A ‘Watch Dog’ of Australia’s Counter-Terrorism Laws: the Coming of the National Security Legislation Monitor' (2011) UNSW Law Research Paper No. 2011-26 4, 23-5; Colm O'Cinneide, 'Strapped to the Mast: the Siren Song of Dreadful Necessity, the United Kingdom Human Rights Act and the Terrorist Threat' in Miriam Gani and Penelope Matthews (eds), Fresh Perspectives on the 'War on Terror (ANU Press 2008) 353.

${ }^{23}$ David Anderson, Report on the Operation in 2010 of the Terrorism Act 2000 and of Part 1 of the Terrorism Act 2006 (2011) 17.

${ }^{24}$ Anderson (n 9) 5-6.

${ }^{25}$ Home Office, Independent Reviewer of Terrorism Legislation Recruitment Information Pack (August 2016$) 4$.

${ }^{26}$ Anderson (n 9) 3.

${ }^{27}$ David Feldman, 'Parliamentary Scrutiny of Legislation and Human Rights' [2002] Public Law 323, 328.

${ }^{28}$ Adam Tomkins, cited in Nicholas Bamforth, 'Accountability', in Nicholas Bamforth and Peter Leyland (eds), Accountability in the Contemporary Constitution (OUP 2013).

${ }^{29}$ Mark Elliott, 'Ombudsmen, Tribunals, Inquiries', in Nicholas Bamforth and Peter Leyland (eds), Accountability in the Contemporary Constitution (Oxford University Press, 2013) 234.

${ }^{30}$ Ibid. 
security service's internal review of the terrorist attacks in London and Manchester in 2017. After describing these trends, the article looks to see whether the Coalition and Conservative governments' approach to counter-terrorism review mark a departure from previous policies under Labour governments from 1997 to 2010. The article concludes by highlighting some overarching themes that can be discerned about Conservative approaches to civil liberties from this study of review of counter-terrorism.

\section{Coalition and Conservative approaches to Counter-Terrorism Review}

This section of the article highlights three trends in Coalition and Conservative approaches to counter-terrorism review: diminished parliamentary scrutiny, the establishment or revision of key accountability organisations, and the use of independent scrutiny of internal reviews.

\section{Diminished Parliamentary Scrutiny}

The first trend in the Coalition and Conservative governments' approach to accountability that can be highlighted is one of reduced opportunities for parliamentary scrutiny of counterterrorism. This is not particularly surprising; a strong executive and weak legislature is one of Ewing and Gearty's critiques of the Thatcher government. ${ }^{31}$ What is a little surprising, is that this trend is apparent even when the Conservative Party was in a Coalition government with the Liberal Democrats from 2010 to 2015, as well as since 2017 when the Conservative Party formed a minority government. The trend can be examined by evaluating the Coalition and Conservative governments' approaches to sunset clauses in anti-terrorism laws, as well as their response to parliamentary committees.

\section{a. Sunset Clauses}

Sunset clauses have traditionally been included in 'emergency' anti-terrorism laws; those deemed to be an exception to the ordinary criminal law. They were used in every anti-terrorism law enacted in the twentieth century in relation to the conflict in Northern Ireland, starting from the Civil Authorities (Special Powers) Act (Northern Ireland) 1922, through to the more modern Northern Ireland (Emergency Provisions) Act 1973 and the Prevention of Terrorism (Temporary Provisions) Act 1974. Sunset clauses were used when measures were considered to be truly exceptional, but also necessary to deal with a particular crisis. Thus, the Northern Ireland (Emergency Provisions) Act 1973, which was enacted during the height of the violence in Northern Ireland and which included measures to detain terrorist suspects prior to charge for up to 72 hours, to proscribe terrorist organisations, to try terrorists in courts sitting without a jury, and to intern terrorist suspects, contained a clause that meant the legislation would lapse at the end of a year, unless the Secretary of State laid an order before Parliament to renew the legislation for another year. ${ }^{32}$ The Prevention of Terrorism (Temporary Provisions) Act 1974, enacted a year later, created a range of measures that applied not just to Northern Ireland, but the whole of the UK. Enacted in the aftermath of the Guildford and Birmingham pub bombings, the Act created a regime to proscribe terrorist organisations, enabled the Secretary of State to exclude suspected terrorists from Great Britain (to Northern Ireland), established a seven-day period of pre-charge detention, and created a range of terrorist offences. The purpose of the six-month sunset clause, ${ }^{33}$ was to give Parliament an opportunity to debate the legislation at a future date when the crisis was not so prescient. Sunset clauses were thus designed as accountability mechanisms, to enable Parliament, at regular intervals, to review the legislation, and consider whether it was still necessary, and if not, to let it lapse.

\footnotetext{
${ }^{31}$ Ewing and Gearty (n 17) 6-7.

32 Northern Ireland (Emergency Provisions) Act 1973 s 30.

${ }^{33}$ Prevention of Terrorism (Temporary Provisions) Act 1974 s 12. See also, for example: Prevention of Terrorism (Temporary Provisions) Act 1976 s 14.
} 
When the Coalition government came to power in 2010, three existing anti-terrorism laws contained sunset clauses: the Prevention of Terrorism Act 2005, which established the control order regime and which required annual renewal; ${ }^{34}$ the section of the Terrorism Act 2006 which extended the maximum period of pre-charge detention to 28 days, but required annual renewal to prevent the pre-charge detention period returning to 14 days ${ }^{35}$ and the Terrorist AssetFreezing (Temporary Provisions) Act $2010,{ }^{36}$ which was enacted as a temporary stop gap with a two year limit to enable Parliament to replace the Terrorism (United Nations Measures) Order 2006 which was quashed by the UK's Supreme Court on the grounds that the use of delegated legislation to implement UN measures was ultra vires the United Nations Act 1946. ${ }^{37}$

Shortly after the 2010 general election, the Coalition government sought to renew the extended period of pre-charge detention for six months, pending its Review of Counter-Terrorism and Security Powers. ${ }^{38}$ The Home Secretary Theresa May, stated her preference that the maximum period should be reduced to 14 days, but that it would be inappropriate to pre-empt the findings of the review. ${ }^{39}$ She thus called on Parliament to renew the legislation one last time, on the grounds that this time it truly would be a temporary extension and an abrogation of the norm. ${ }^{40}$ In January 2011, May did not lay another order before Parliament to retain the 28-day maximum period of pre-charge detention, and it reverted to 14 days. In 2012, the Terrorist Asset Freezing (Temporary Provisions) Act 2010 was replaced with the Terrorist Asset Freezing etc. Act 2012 just as the sunset clause was due to set. Finally, in 2011, the Prevention of Terrorism Act 2005 was renewed at its sunset clause, but only for six months, pending the outcome of the Review of Counter-Terrorism and Security Powers. In December 2011, when that six months was up, the Coalition government introduced new legislation to repeal and replace control orders in the Prevention of Terrorism Act 2005 with TPIMs. ${ }^{41}$ Where the Prevention of Terrorism Act 2005 required annual renewal by Parliament, the Terrorism Prevention and Investigation Measures Act 2011 contained a five-year sunset clause, ${ }^{42}$ which could be renewed by Parliament if the Secretary of State laid an order before it to do so. ${ }^{43}$ The legislation was renewed in 2016, with very limited parliamentary debate. The House of Commons decided to debate the renewal order in the delegated legislation committee, rather than in the whole House. Debate lasted just 32 minutes. ${ }^{44}$ The Lords took even less time. Three participants considered whether to renew the measures for just 17 minutes. ${ }^{45}$ The Terrorism Prevention and Investigation Measures Act 2011 was thus extended for another five years following less than an hour's debate in Parliament. It will now lapse in 2021 unless the Secretary of State introduces a new order to renew it. One of the core reasons for introducing a longer sunset clause for TPIMs (five years) than for control orders (one year) was that the Terrorism Prevention and Investigation Measures Act 2011 provided a rebalancing in favour of liberty; some of the most rights restrictive measures were removed, in particular the Home Secretary's power to order a curfew and to relocate terrorist suspects away from their usual place of residence. However, in 2015, some of these measures, notably the power to relocate

\footnotetext{
${ }^{34}$ Prevention of Terrorism Act 2005 s 13.

35 Terrorism Act 2006 s 25.

36 Terrorist Asset- Freezing (Temporary Provisions) Act 2010 s 1(1).

${ }^{37}$ HM Treasury $v$ Ahmed [2010] UKSC 2, [2010] 2 AC 534.

${ }^{38}$ HC Deb 14 July 2010, vol 513, cols 1006-1008; HL Deb 19 July 2010, vol 720, col 853.

${ }^{39}$ HC Deb 14 July 2010, vol 513, col 1008.

40 Ibid.

${ }^{41}$ Terrorism Prevention and Investigation Measures Act 2011 s 1.

${ }^{42}$ Ibid s 21(1).

${ }^{43}$ Ibid s 21(2).

${ }^{44}$ Delegated Legislation Committee Deb 26 October 2016, vol 616, cols 1-12.

${ }^{45}$ HL Deb 24 November 2016, vol 776, cols 2136-2140.
} 
terrorist suspects, were incorporated into the TPIMs regime. ${ }^{46}$ It is therefore questionable whether the existing accountability framework is sufficiently robust to deal with these changes in circumstances. The absence of any real debate on the renewal order in 2011 suggests that Parliament's capacity to hold the government to account through this mechanism is particularly weak, especially where civil liberties are concerned.

Thus, the use of sunset clauses has actually diminished under the Coalition and Conservative governments since 2010, as will be demonstrated in the section on the Labour government's use of sunset clauses between 1997 and 2010. Where sunset clauses have been incorporated into legislation, it has been for longer periods of time than those introduced in legislation enacted by Parliament under the Labour government. Other key anti-terrorism legislation, such as the Counter-Terrorism and Security Act 2015, does not include a sunset clause at all, meaning that despite the controversial nature of some of its measures - for example the power of the Secretary of State to temporarily exclude UK citizens suspected of being abroad to engage in terrorism from entering the UK - the legislation is permanent, and Parliament will not have a designated future opportunity to review it and decide on its continuing necessity.

\section{b. Parliamentary Committees}

The Conservative approach to accountability conducted by parliamentary committees can perhaps best be ascertained from its attitude to appointments to the JCHR following the 2017 general election, which took place on 8 June. The House of Lords nominated its members of the Committee on 19 July, but the Commons did not nominate its members until 30 October, nearly nine months after the election. ${ }^{47}$ The Coalition and Conservative governments' response to reports by the JCHR reveals a similar attitude towards accountability for civil liberties.

The JCHR has not undertaken any reviews of counter-terrorism legislation since the 2017 general election, nor did it conduct any during the 2015 to 2017 Conservative government. ${ }^{48}$ However, the JCHR produced a number of reports on the human rights implications of counterterrorism laws during the Parliament under the Coalition government. This included reports on control orders, ${ }^{49}$ stop and search powers under the Terrorism Act $2000,{ }^{50}$ Terrorism Prevention and Investigation Measures ${ }^{51}$ the Counter-Terrorism and Security Bill, ${ }^{52}$ and the terrorist assetfreezing regime. ${ }^{53}$ The Coalition and Conservative governments do not appear to have provided any response to these reports. Accountability can only be deemed to be effective if there is

\footnotetext{
${ }^{46}$ Counter-Terrorism and Security Act 2015 ss 16-20.

47 Joint Committee Human Rights, 'Membership'

<http://www.parliament.uk/business/committees/committees-a-z/joint-select/human-rightscommittee/membership/> accessed 23 March 2018.

${ }^{48}$ It did conduct a review of the proposed Counter-Extremism Bill in this period, however that Bill has still not been published. See: Joint Committee on Human Rights, Counter-Extremism (2016-17, HL 39, HC 105).

${ }^{49}$ Joint Committee on Human Rights, Renewal of Control Orders Legislation 2011 (2010-12, HL 106, HC 838).

${ }^{50}$ Joint Committee on Human Rights, The Terrorism Act 2000 (Remedial) Order 2011: Stop and Search without Reasonable Suspicion (2010-12, HL 192, HC 1483); Joint Committee on Human Rights, Terrorism Act 2000 (Remedial) Order 2011: Stop and Search without Reasonable Suspicion (2010-12, HL 155, HC 1141).

51 Joint Committee on Human Rights, Legislative Scrutiny: Terrorism Prevention and Investigation Measures Bill (2010-12, HL 180, HC 1432); Joint Committee on Human Rights, Legislative Scrutiny: Terrorism Prevention and Investigation Measures Bill (Second Report) (2010-12, HL 204, HC 1571); Joint Committee on Human Rights, Post-Legislative Scrutiny: Terrorism Prevention and Investigation Measures Act 2011 (2013-14, HL 113, HC 1014).

52 Joint Committee on Human Rights, Legislative Scrutiny: Counter-Terrorism and Security Bill (2014-15, HL 86, HC 859).

53 Joint Committee on Human Rights, Legislative Scrutiny: Terrorist Asset-Freezing etc Bill (Second Report); and other Bills (2010-12, HL 53, HC 598); Joint Committee on Human Rights, Legislative Scrutiny: Terrorist Asset-Freezing etc. Bill (Preliminary Report) (2010-12, HL 41, HC 535).
} 
some capacity for the reviewing body to shape the activities of the institution reviewed. ${ }^{54}$ Whilst it cannot be said for certain that a failure to respond to a report means that the government paid no attention to the recommendations made therein, it is a pretty good indicator of the Conservative government's approach to accountability.

\section{The Establishment and Revision of Key Accountability Institutions}

This section of the article focuses on the Coalition government's proposal to replace the UK's key counter-terrorism review body, the Independent Reviewer of Terrorism Legislation, with an Independent Privacy and Civil Liberties Board in 2014, as well as the subsequent revisions to the office of Independent Reviewer which were made when that proposal fell through. The establishment of a Commission for Countering Extremism in 2018 is also examined.

\section{a. The Independent Privacy and Civil Liberties Oversight Board}

In 2014, thirty years after the office was established, the Home Office announced that the government intended to replace the Independent Reviewer of Terrorism Legislation with an Independent Privacy and Civil Liberties Board. ${ }^{55}$ The Board's remit would include all of the UK's major anti-terrorism laws. ${ }^{56}$ Unlike the Independent Reviewer, who was required to provide an annual report on each of the laws subject to review, the Board would not be required to review every anti-terrorism law on an annual basis, but would instead set an annual work programme in consultation with the relevant ministers and parliamentary committees. The purpose of the review was to ensure that the laws were 'sufficient to meet the threat and adequately take account of privacy and liberty concerns. ${ }^{57}$ The Board would also:

Advise the Government on whether it considers government policy and its development, including new legislation, relating to the prevention of terrorism is sufficient to meet the threat and adequately takes account of privacy and liberty concerns. Provide public assurance that the current arrangements ensure that the implementation of legislation and policies relating to the prevention of terrorism have sufficient regard to their impact on privacy and civil liberties as well as to the threat. Carry out particular inquiries into the impact of particular issues or legislation relating to the prevention of terrorism, including at the direction of relevant Ministers. Provide evidence to Parliamentary Committees and seek to inform public debate where possible. ${ }^{58}$

The review of anti-terrorism legislation for its impact on civil liberties, albeit with a primacy on privacy, was thus a key feature of the proposed Board. However, there was one major concern with the phrasing of the Board's terms of references; the requirement to 'provide public assurance' that the laws had sufficient regard to privacy and civil liberties concerns whilst meeting the terrorist threat. The heavy focus on assurance, rather than impartial review with all its potential outcomes, could limit the role of post-enactment scrutiny to one which is in the service of government, rather than holding it to account. The former Independent Reviewer of Terrorism Legislation, David Anderson has repeatedly highlighted the importance

\footnotetext{
${ }^{54}$ Christopher Hood, Oliver James, George Jones, Colin Scott and Tony Travers, Regulation Inside Government: Waste-Watchers, Quality Police, and Sleazebusters (OUP 1999), 8.

55 Home Office, 'Independent Privacy and Civil Liberties Board Terms of Reference' <https://www.gov.uk/government/uploads/system/uploads/attachment_data/file/330748/Independent_Privacy_a nd_Civil_Liberties_Board.pdf> accessed 16 March 2018.

56 Including: Terrorism Act 2000; Anti-Terrorism, Crime and Security Act 2001; Prevention of Terrorism Act 2005; Part 1 of the Terrorism Act 2006; Counter-Terrorism Act 2008; Terrorist Asset-Freezing etc. Act 2010; and Terrorism Prevention and Investigation Measures Act 2011. Home Office (n 55).

${ }^{57}$ Home Office (n 55).

58 Ibid.
} 
of the neutrality and independence of the position of Independent Reviewer. For example, he has noted that it is not his role to 'torment the Government, or conversely to defend it'. ${ }^{59}$ The purpose of his position is 'only to give an informed, considered and independent view'. ${ }^{60}$ Furthermore, he has acknowledged that whilst the office can serve to reassure the public, it is not required to do so and is also there, when necessary, to 'raise the alarm. ${ }^{61}$ This was not the only criticism levelled at the government's proposal to establish an Independent Privacy and Civil Liberties Board. Anderson raised two further concerns about the Board's capacity to conduct effective scrutiny of the impact of counter-terrorism on civil liberties: the proposal to include pre-legislative scrutiny within the Board's remit; and the composition of the Board as a panel, rather than an individual reviewer.

One major concern with including pre-legislative scrutiny in the Board's remit, in addition to post-enactment review, is that by engaging in pre-legislative scrutiny, the Board may unintentionally undermine its credibility to perform post-enactment review. There is a risk, for example, that if the Board 'approves' a measure during its pre-legislative inquiry then any subsequent critique of the Act in operation might not find a particularly receptive audience with a government which can point to the earlier positive review of the legislation. This was noted by Anderson in his evidence to the JCHR's inquiry into the Counter-Terrorism and Security Bill. Anderson refused to comment on the legality of the proposed measures on the grounds that he did not 'think it would be a very good start if I announced right at the beginning that they were obviously lawful or unlawful. ${ }^{62}$ The same argument could be made against scrutiny for civil liberties, particularly as the role of the Board was to provide public assurance that legislation is compatible with civil liberties. If the Board had previously assured the public that a parliamentary bill raised no privacy or civil liberties concerns before it was enacted, it might find it difficult to convince the public and the government with an opposite assessment during its post-legislative scrutiny of the law.

The final concern relates to the quality of the review that might be conducted by a Board constituted as a Panel, rather than an individual reviewer. Whilst there are arguments in favour of a panel of reviewers - for example, that it can offer a 'spread of expertise' 63 and ensure continuity, 'so that a range of expertise and familiarity with the laws and the review process is held by those serving in the office at any one time ${ }^{64}$ - Anderson highlighted some of the potential negative impacts on the quality of the review that a panel might incur. These included that high-quality candidates might be deterred from applying for a long-term full-time position. Furthermore, because members of the Board would not have sole responsibility for its output, Anderson considered that 'there is a strong risk that they will focus their efforts elsewhere and leave much of the work to be done by the secretariat or by others ${ }^{65} \mathrm{He}$ also noted that the effectiveness of the review process, which currently relies on the Independent Reviewer being granted full access to secret material held by the government and intelligence and security

\footnotetext{
${ }^{59}$ David Anderson, 'The Independent Review of Terrorism Laws' [2014] Public Law 403, 409.

60 Ibid.

${ }^{61}$ David Anderson, 'The Independent Review of UK Terrorism Law' (2014) 5(4) New Journal of European Criminal Law 432, 446.

62 Joint Committee on Human Rights, Uncorrected Transcript of Oral Evidence Counter-Terrorism and Human Rights (26 November 2014), 11 [Q15].

${ }^{63}$ Clive Walker, 'The United Kingdom's Anti-Terrorism Laws: Lessons for Australia', in Andrew Lynch, Edwina McDonald and George Williams (eds), Law and Liberty in the War on Terror (The Federation Press, 2007$) 189$. ${ }^{64}$ Gilbert + Tobin Centre of Public Law, 'Submission to the Senate Legal and Constitutional Affairs Committee Inquiry into the Independent Reviewer of Terrorism Laws Bill 2008 [No. 2]' (10 September 2008) <http://www.gtcentre.unsw.edu.au/sites/gtcentre.unsw.edu.au/files/mdocs/Submission_Independent_Reviewer Bill \%20-Sept08.pdf> accessed 16 March 2018.

${ }^{65}$ David Anderson, The Terrorism Acts in 2013 (2014) 100.
} 
agencies, 'could be severely diminished' if the same access was denied to all members of a Board. ${ }^{66}$

As well as these disadvantages, Anderson noted two core advantages that an individual has over a panel of reviewers. First, that 'A single occupant of the post has the chance to build personal relations with parliamentarians, media and others; and is accountable for every word written or spoken. This drives up the quality of the work, and lends immediacy and recognition to a post which could be faceless if performed by a committee. ${ }^{67}$ Secondly, the independence of the office is paramount to its ability to review the laws effectively. An individual appointed on a part-time basis retains their professional career and is thus not dependent on the government as the sole source of income. In contrast, Anderson noted that a 'Reviewer whose livelihood depended on re-appointment (or on appointment to another post within the gift of Ministers) would be difficult to describe as fully independent. ${ }^{68}$ A further limitation on the composition of the Board is the power of the Secretary of State to make regulations that could negatively affect the independence of Board members, including about:

(a) the membership of the board; (b) the payment of expenses and allowances to members; (c) the circumstances in which a person ceases to be a member; (d) the appointment of staff, their terms and conditions of employment and their pensions, allowances or gratuities; (e) the organisation and procedure of the board; (f) particular things that the board may or must do; (g) the preparation and publication of reports and accounts. ${ }^{69}$

Finally, highlighting the important role that access to classified material plays in the review of the UK's anti-terrorism laws, Anderson concluded: 'In short, such a Board if properly constituted could bring advantages: but the wrong decisions could substantially diminish the value that is offered by the current arrangements, particularly if there were any reluctance to share classified information with a larger and more varied group. ${ }^{, 70}$ These would all impact negatively on the Board's capacity to scrutinise the impact of the relevant counter-terrorism laws on civil liberties.

Ultimately, the government reversed its decision to replace the Independent Reviewer with the Independent Privacy and Civil Liberties Board, and instead opted to create a Privacy and Civil Liberties Board as a supplement to independent review. ${ }^{71}$ The Board was due to be brought into existence by the Secretary of State by statutory instrument, yet it currently languishes unestablished on the statute books. This is likely the result of the change in government in 2015; the proposal to establish a Board was, in part, a product of the Coalition government. The impetus for bringing the Privacy and Civil Liberties Board to life appears to have been lost following the Conservative Party's 2015 general election victory. ${ }^{72}$

At the same time as establishing the Privacy and Civil Liberties Board, the Counter-Terrorism and Security Act 2015 also updated various aspects of the office of the Independent Reviewer of Terrorism Legislation.

\section{b. Independent Reviewer of Terrorism Legislation}

\footnotetext{
${ }^{66}$ Ibid.

${ }^{67}$ Ibid.

68 Ibid

${ }^{69}$ Counter-Terrorism and Security Act 2015 s 46(3).

${ }^{70}$ Anderson (n 65) 100-101.

${ }^{71}$ Counter-Terrorism and Security Bill (2014-15) cl 36.

72 Alan Travis, 'New privacy and civil liberties board to look at security policy, says Nick Clegg' The Guardian (16 October 2014).
} 
The Counter-Terrorism and Security Act 2015 significantly expanded the mandate of the Independent Reviewer of Terrorism Legislation. The person appointed to review the Terrorism Act 2000 and Part 1 of the Terrorism Act 2006 - the 'Independent Reviewer' - was also made responsible for reviewing the operation of Part 1 and Part 2 of the Anti-Terrorism, Crime and Security Act 2001; the whole of the Counter-Terrorism Act 2008; and Part 1 of the CounterTerrorism and Security Act 2015. ${ }^{73}$ The separate mandate to review the Terrorist AssetFreezing etc. Act 2010 and the Terrorism Prevention and Investigation Measures Act 2011 is retained under those Acts. ${ }^{74}$ The most significant change to the terms of reference of the office is in the timing of reviews. Whilst previously the Independent Reviewer was required to review the operation of every Act with a review clause on an annual basis, he or she has now been given discretion to select which aspects of the legislation to review each year, ${ }^{75}$ with the exception of the UK's permanent anti-terrorism law, the Terrorism Act 2000 which must still be reviewed annually. ${ }^{76}$ The Independent Reviewer must simply notify the Secretary of State by 31 January each year of what reviews the office intends to carry out that year. This change was intended to improve the quality of the review process; as the Independent Reviewer was no longer required to review each law every year, the office could focus on detailed reviews of key powers. The effect should have been to provide depth, rather than breadth to the reviews. This was a change that the then Independent Reviewer, David Anderson pushed for. Referring to the 'inflexible schedule' that he had previously operated under, Anderson noted that 'the Independent Reviewer was required to review each of the laws subject to review every year, regardless of whether those laws had been used or not. ${ }^{77}$ The 2015 changes meant that this was no longer the case.

In practice, the change has not brought about the expected positive results of fewer, but more in-depth reviews of the most controversial counter-terrorism laws. Since the changes were made in 2015, only the Terrorism Act 2000 and Part 1 of the Terrorism Act 2006 have been subject to review by the Independent Reviewer. ${ }^{78}$ In January 2016, in line with the new procedures, David Anderson notified the Secretary of State that he intended to conduct a review of executive powers that year. ${ }^{79}$ This included some of the most rights restrictive counterterrorism measures available, such as TPIMs and Temporary Exclusion Orders, which had recently been created in the Counter-Terrorism and Security Act 2015. However, shortly after notifying the Secretary of State of his intended work plan, the government commissioned Anderson to conduct a review of the operational case for bulk intelligence powers. ${ }^{80}$ That review was completed and published in August 2016. ${ }^{81}$ In 2016 Anderson also completed a review of the Secretary of State's powers under the Immigration Act 2014 to revoke the

\footnotetext{
${ }^{73}$ Counter-Terrorism and Security Act 2015 s 44(2).

${ }^{74}$ Terrorist Asset-Freezing etc. Act 2010 s 31; and Terrorism Prevention and Investigation Measures Act 2011 s 20.

${ }^{75}$ Counter-Terrorism and Security Act 2015 s 45.

${ }^{76}$ Counter-Terrorism and Security Act 2015 s 45(1)(a).

77 David Anderson, 'CT Oversight: A time for a decision' (13 December 2014) <http://webarchive.nationalarchives.gov.uk/20170301151425/https://terrorismlegislationreviewer.independent.g ov.uk/oversight-of-counter-terrorism-powers/> accessed 14 May 2018.

${ }^{78}$ David Anderson, The Terrorism Acts in 2014 (2015); David Anderson, The Terrorism Acts in 2015 (2016); Max Hill, The Terrorism Acts in 2016 (2018).

79 David Anderson, 'Work Plan for 2016 - Letter to the Home Secretary' (3 February 2016) <http://webarchive.nationalarchives.gov.uk/20170301151653/https://terrorismlegislationreviewer.independent.g ov.uk/category/feature/page/3/> accessed 23 March 2018.

80 David Anderson, 'Bulk Powers Review Announced' (7 June 2016) < http://webarchive.nationalarchives.gov.uk/20170301151710/https://terrorismlegislationreviewer.independent.g ov.uk/bulk-powers-review/> accessed 23 March 2018.

${ }^{81}$ David Anderson, Report of the Bulk Powers Review (Cm 9326, 2016).
} 
citizenship of naturalised British citizens even where that would lead to statelessness, ${ }^{82}$ and continued work on his review the government's deportation with assurances policy, which was published in $2017 .^{83}$ In 2017, Anderson did not notify the government of his intended workplan that year, as he had submitted his resignation to take effect from February. ${ }^{84}$ His successor, Max Hill QC, was appointed after the deadline to notify the Secretary of State of that year's work plan. Understandably, he spent his first year focusing on conducting the required review of the Terrorism Act 2000. It is not yet clear whether Hill has submitted a workplan in 2018; one has not been published either on the Independent Reviewer's website, or by the Home Office. Thus the effect of the changes made in 2015 has been that the only legislation reviewed by the Independent Reviewer has been the Terrorism Act 2000 and Part 1 of the Terrorism Act 2006. There has been no review of TPIMs for the past three years, despite the significant expansion of the regime in 2015, including the introduction of a measure that enabled the Secretary of State to relocate TPIM subjects up to 200 miles from their current residence. The impact on civil liberties of these new measures, is thus unknown. Whilst reviews of the Terrorism Act 2000 are an important accountability mechanism, some of the most rights restrictive measures are contained in anti-terrorism laws which have not been reviewed for some significant time, and it not clear when they will be reviewed in the future.

\section{c. Commission for Countering Extremism}

In 2017, the Conservative government announced the establishment of a Commission for Countering Extremism, to be headed by a Counter-Extremism Commissioner. ${ }^{85}$ The Commission emerged following the government's failure to identify a legally viable definition of non-violent extremism which could be used in its proposed legislation, the as yet unpublished but much publicised Counter-Extremism Bill. This sought to establish measures that could be used to ban extremist organisations, akin to the proscription measures available for terrorist organisations, and which would enable the Home Secretary to place restrictions, obligations and duties, similar to those available under the TPIMs regime for suspected terrorists, on suspected non-violent extremists.

In 2018, the Home Secretary appointed Sarah Khan to the role of Counter-Extremism Commissioner and set out a Charter for the Commission. It is to be a 'transparent body operating independently of government,${ }^{86}$ with a remit to

support the government, the public sector, civil and wider society and families to identify and challenge all forms of extremism. It will provide the government with impartial, expert advice on the tools, policies and approaches needed to tackle extremism; it will support the public sector, communities and civil society to confront extremism wherever it exists; and it will promote a positive vision of our core, shared values. ${ }^{87}$

As such, it does not have a traditional accountability function, in that its purpose is advising the government, rather than holding it to account. How it works in practice, and the extent to which it guides government policy on countering extremism, including any future Counter-

\footnotetext{
${ }^{82}$ David Anderson, Citizenship Removal Resulting in Statelessness (2016).

${ }^{83}$ David Anderson, Deportation with Assurances (Cm 9462, 2017).

84 David Anderson, 'Moving In - Moving On' $\quad(31 \quad$ March 2016) <http://webarchive.nationalarchives.gov.uk/20170301151442/https://terrorismlegislationreviewer.independent.g ov.uk/moving-in-moving-on/> accessed 23 March 2018.

${ }^{85}$ Queen's Speech 2017 (21 June 2017).

${ }^{86}$ Home Office, Charter for the Commission for Countering Extremism (2018).

${ }^{87}$ Ibid.
} 
Extremism Bill, will reveal whether it can have a restraining influence on the government that helps to promote, rather than repress civil liberties.

\section{Independent Scrutiny of Internal Counter-Terrorism Reviews}

Reviews that provide independent scrutiny of internal government reviews of counter-terrorism legislation appear to be an innovation of the Coalition and Conservative governments. Two reviews have been established to provide that independent scrutiny: in 2010, Lord Macdonald of Riverglaven was appointed to review the Home Office Review of Counter-Terrorism and Security Powers; and in 2017, David Anderson, the recently retired Independent Reviewer of Terrorism Legislation, was appointed to provide independent oversight of the police and security service internal review of the terrorist attacks in London and Manchester.

\section{a. Independent Review of the 2010 Review of Counter-Terrorism and Security Powers}

Shortly after the 2010 general election, in line with the Coalition Programme for Government's goal to rebalance counter-terrorism powers in favour of liberty, the Home Office instituted a Review of Counter-Terrorism and Security Powers, which was conducted in house by the Office for Security and Counter-Terrorism. The Home Office appointed Lord Macdonald to review that process. Lord Macdonald was asked to: 'provide independent oversight of the Review' and to 'ensure that it is properly conducted, that all the relevant options have been considered and the recommendations are balanced. ${ }^{88}$ Lord Macdonald provided a review of each of the measures subject to the government's Review of Counter-Terrorism and Security Powers. At times, he agreed with the findings of that review, however, he was not averse to highlighting when the government had failed to sufficiently take account of civil liberties. In assessing whether the restrictions that could be placed on a person subject to a control order should be retained, Lord Macdonald noted where the government's recommendations were not sufficiently specific to ensure rights and liberties were protected. For example, referring to the government's review of prohibitions on the use by controlees of telephones and the internet, Lord Macdonald stated: "Beyond conceding that "some restrictions on communication will be required" but that there will be "greater freedom of communication" with only "limited restrictions", the Review does not elaborate. This failure to spell out its thinking in greater detail is an omission. ${ }^{89} \mathrm{He}$ drew similar conclusions about the quality of the government's review of restrictions on association ${ }^{90}$ and movement. ${ }^{91}$ Lord Macdonald thus demonstrated a willingness to highlight where the government's internal review had - in his view - failed to sufficiently take account of concerns regarding the impact of counter-terrorism laws on civil liberties. He concluded his review with the following warning: 'Further explanation from the government of the precise circumstances in which it believes that any remaining restrictions may properly be placed upon individuals in the absence of criminal investigation, charge or conviction, will reveal how far ministers intend to drive this important process [of rebalancing policy in favour of liberty]' ${ }^{92}$

b. 'Independent Assurance' of Police and MI5 Internal Reviews of the London and Manchester Terrorist Attacks

In response to the four terrorist attacks that took place from March to June $2017,{ }^{93}$ MI5 and the National Counter-Terrorism Police initiated internal reviews to 'look at what was known and

\footnotetext{
${ }^{88}$ Lord Macdonald, Review of Counter-Terrorism and Security Powers (Cm 8003, 2011) 1.

${ }^{89}$ Ibid 14.

${ }^{90}$ Ibid $14-15$.

${ }^{91}$ Ibid 15 .

92 Ibid 16.

93 Westminster Bridge, 22 March 2017, Manchester Arena, 22 May 2017, London Bridge, 3 June 2017, and Finsbury Park, 19 June 2017.
} 
how investigative processes and decision making operated prior to the attacks, and whether any further improvements can be made to help stop future terrorism. ${ }^{94}$ Home Secretary Amber Rudd invited David Anderson to conduct an 'independent assurance of these internal reviews', which she hoped would provide her 'and the rest of the National Security Council confidence that all the relevant questions in relation to what was known and done before the attacks have been addressed, and the appropriate conclusions drawn. ${ }^{95}$ Anderson noted that independent assurance could mitigate against the potential downsides of the internal review, which he identified as 'complacency, the concealment of unpalatable facts and slowness to see the need for change. ${ }^{96}$ Anderson reviewed all nine internal reviews conducted by the police and MI5, both during the process of the internal review as well as the final reports. ${ }^{97}$ Because of the need to provide assurance as to the quality of the internal reviews, Anderson notes that he:

made specific comments on drafts, asked for proof of assertions, requested documents and briefings, identified issues to be confronted, asked for more thorough accounts, suggested the restructuring of reports, challenged assertions that errors were inconsequential, advised that sensitive material was relevant, discouraged complacency and generally sought to promote the value of selfcriticism. On a limited number of issues I also made the case, sometimes forcefully, for the consideration of specific operational improvements or for further-reaching recommendations than previous drafts had been prepared to contemplate. ${ }^{98}$

Ultimately, Anderson was satisfied with the quality of the internal reviews and endorsed their conclusions and recommendations. ${ }^{99}$ The internal reviews produced 126 recommendations, which Anderson was subsequently asked to review the implementation of - a 'stocktake' of implementation. ${ }^{100}$ It is to be completed by the end of January 2019, twelve months after the internal reviews were completed. Anderson must report on the progress that has been made in implementing the recommendations of the internal review and provide conclusions on this to the Home Secretary. This is a novel and potentially strong accountability mechanism, designed to ensure that recommendations are not simply allowed to fall by the wayside. Its strength as a means to hold the police and security service to account will be revealed in January 2019.

Accountability for counter-terrorism, particularly scrutiny of the civil liberties aspects of antiterrorism legislation, has not been a high priority for the Coalition and Conservative governments, with the exception of the unsuccessful attempt to establish a new body - the Independent Privacy and Civil Liberties Board - to scrutinise the impact of anti-terrorism legislation on civil liberties, with a focus on privacy. Whether this is a significant departure from the approach adopted by the Labour governments of 1997 to 2010, is the subject of the next section of this article.

\section{Labour's Approach to Counter-Terrorism Review}

When the Labour Party was elected into government in 1997, it inherited the anti-terrorism laws enacted under the previous Conservative governments; the Prevention of Terrorism

\footnotetext{
${ }^{94}$ Security Service, 'MI5 and Police - Joint Review of Operation Processes in CT Investigations Following Recent Terrorist Attacks' <https://www.mi5.gov.uk/fr/node/496> [accessed 16 March 2018].

${ }^{95}$ Letter from the Home Secretary Amber Rudd to David Anderson, 28 June 2017, quoted in David Anderson, Attacks in London and Manchester (2017) 36.

96 David Anderson, Attacks in London and Manchester (2017) 7.

${ }^{97}$ Ibid 37.

${ }^{98}$ Ibid 41.

${ }^{99}$ Ibid 48.

100 David Anderson, 'Watching the Watchers - Implementation Stocktake' (30 January 2018) <https://www.daqc.co.uk/2018/01/30/watching-the-watchers-implementation-stocktake/> accessed 16 March 2018.
} 
(Temporary Provisions) Act 1989 and the Northern Ireland (Emergency Provisions Act 1991. These Acts required annual renewal, otherwise they would lapse. The Labour government also inherited the Northern Ireland peace process, which led to the Belfast Agreement of $1998 .{ }^{101}$ As part of the peace process, the Conservative government had initiated a review of the antiterrorism legislation, which was conducted by Lord Lloyd and published in $1996 .{ }^{102}$ Lord Lloyd was asked to consider whether, if there was a lasting peace in Northern Ireland, some form of anti-terrorism legislation would still be necessary. He considered that it would, and after the election, the Labour government set about to consolidate the existing emergency and temporary anti-terrorism laws. ${ }^{103} \mathrm{~W}$ ith the exception of special temporary provisions relating to the security situation in Northern Ireland, ${ }^{104}$ the Terrorism Act 2000 was a permanent feature of the statute book. The next decade of Labour government was characterised by a focus on counter-terrorism, in response to terrorist attacks both at home and abroad. The approach to accountability in the same period, particularly in terms of scrutiny of the impact of antiterrorism laws on civil liberties, is the result of that particular context. This section of the article identifies whether the trends highlighted in the Coalition and Conservative governments' approach to accountability for counter-terrorism marks a radical departure from, or is simply a continuation of, Labour government approaches in the first decade of the twenty-first century.

\section{Diminished Parliamentary Scrutiny}

In terms of parliamentary scrutiny of counter-terrorism, there is very little to distinguish the Coalition and Conservative governments since 2010 from the Labour governments that preceded them.

\section{a. Sunset clauses}

It was under the Labour government that anti-terrorism legislation was first made a permanent feature on the statute books. The Terrorism Act 2000 did not contain a sunset clause, except for the Part 7 provisions which were specific to Northern Ireland. This meant that, for the first time, the UK's main anti-terrorism legislation would not require either annual or periodic renewal. Parliament's ability to scrutinise that legislation after enactment was thus immediately diminished. However, in the legislation introduced by the Labour government in the nine years after the September 11 terrorist attacks, sunset clauses were incorporated where measures were deemed exceptional or particularly controversial. This included the Part 4 indefinite detention provisions of the Anti-Terrorism, Crime and Security Act 2001 which had a sunset clause at 15 months, ${ }^{105}$ then annually, ${ }^{106}$ with a five-year limit in total. ${ }^{107}$ The Prevention of Terrorism Act 2005, which established the controversial control order regime, contained a one-year sunset clause, requiring annual renewal by Parliament. ${ }^{108}$ The Terrorism Act 2006 was not as a whole subject to a sunset clause, but a one-year sunset clause was included for section 23 , which extended the maximum period of pre-charge detention from 14 to 28 days. ${ }^{109}$ Finally, the Terrorist Asset-Freezing (Temporary Provisions) Act 2010 had a sunset clause which meant that the legislation would expire on 31 December 2010, with no opportunity for renewal. ${ }^{110}$

\footnotetext{
${ }^{101}$ The Belfast Agreement: An Agreement Reached at the Multi-Party Talks on Northern Ireland (Cm 3883, 1998).

102 Lord Lloyd, Inquiry into Legislation Against Terrorism (Cm 3420, 1996).

${ }^{103}$ HM Government, Legislation Against Terrorism A Consultation Paper (Cm 4178, 1998).

${ }^{104}$ Contained within Part 7 of the Act, these provisions had both an annual renewal mechanism (Terrorism Act $2000 \mathrm{~s} 112(1))$ and a five year sunset clause (Terrorism Act $2000 \mathrm{~s}$ 112(4)).

105 Anti-Terrorism, Crime and Security Act 2001 s 29(1).

106 Ibid s 29(2).

${ }^{107}$ Ibid s 29(7).

${ }^{108}$ Prevention of Terrorism Act 2005 s 13(1).

109 Terrorism Act 2000 s 25.

110 Terrorist Asset-Freezing (Temporary Provision) Act 2010 s 1.
} 
Whilst a number of the anti-terrorism laws enacted under the Labour government then provided for future parliamentary scrutiny, including scrutiny of the impact of the laws on civil liberties, in practice, parliament's record of holding the government to account has not been particularly robust.

For example, on the first annual renewal of the Part 4 indefinite detention provisions of the Anti-Terrorism, Crime and Security Act 2001, the House of Commons was granted only one and a half hours of debate. ${ }^{111}$ Those who participated focused on two main themes: the terrorist threat level to the UK (in the wake of the terrorist attack in Bali earlier that year), ${ }^{112}$ and the review process, ${ }^{113}$ with very little discussion of the actual content of the legislation. It was, however, significantly better than that which took place in the House of Lords, in which only four Lords, including the Minister who laid the draft order, participated. ${ }^{114}$ This, unfortunately, is reflective of many of the renewal debates held in parliament on anti-terrorism laws. Debates in the House of Commons on the Prevention of Terrorism Act 2005 were also limited to an hour and a half, leaving little opportunity for members to question and critique the control order powers. This point was raised by Dr Evan Harris, during the 2008 renewal debate, he stated:

there is a problem of inadequate parliamentary scrutiny ... Parliamentary scrutiny is rubbish when it comes to control order renewal - I think that the Minister was on his way to accepting that. There should be more than a one and a half hour debate so that we do not have to rush the points that we wish to make'. ${ }^{115}$

However, more time for debate might not have made a significant difference to the level of scrutiny provided, as most debates enjoyed only limited attendance - the first renewal debate on the Prevention of Terrorism Act 2005, for example, was attended by just thirteen MPs ${ }^{116}$

Some of absence of accountability here can be attributed to how the sunset clauses are drafted. Even though Parliament can debate the merits of the substantive content of the legislation, it only has one of two choices: to renew the legislation for the designated period, or to allow it to lapse. No changes to the substantive content of the laws can be made during the renewal process. Parliament was reluctant to vote against continuing temporary measures in force under the Labour government; in fact, it did not do so.

Thus, unlike under the Coalition and Conservative governments, sunset clauses were a typical feature of controversial anti-terrorism laws under the Labour government. They were also for shorter periods than those used under the Coalition and Conservative governments since 2010, granting Parliament more frequent opportunities to scrutinise the laws. However, Parliament did not make the most of its capacity to review the legislation; debates were not well attended, discussion rarely focused on the substantive content of the laws, and the debates were typically restricted to just an hour and a half, though sometimes they did not even last that long.

\section{b. Parliamentary Committees}

The Joint Committee on Human Rights was established under the Labour government as part of the system of political rights review created by the enactment of the Human Rights Act

\footnotetext{
${ }^{111}$ HC Deb 3 March 2003, vol 400, col 604.

112 HC Deb 3 March 2003, vol 400, cols 584; 586; 588; 589.

${ }^{113}$ HC Deb 3 March 2003, vol 400, cols 592-593; 598-599; 601; 606.

${ }^{114}$ HL Deb 11 March 2003, vol 645, cols 1291-1300. The Lords who participated in the debate raised a number of concerns with the legislation with the Minister but did not seek to divide the House on the question of whether to approve the motion.

${ }^{115}$ HC Deb 21 February 2008, vol 472, col 583.

116 This was pointed out by Alistair Carmichael during the debate. HC Deb 15 February 2006, vol 442, col 1516.
} 
1998. ${ }^{117}$ It published a considerable number of reports on the anti-terrorism legislation enacted under Labour governments in the first decade of the twenty-first century. The government's response to the Committee's reports on control orders is reflective of its broader approach to parliamentary scrutiny of the impact of anti-terrorism laws on civil liberties.

The JCHR published a number of critical reports on the Prevention of Terrorism Act 2005, suggesting major recommendations on a range of issues, both to the text of the law and to the operation of the regime in practice. It also put forward the view that parts of the Prevention of Terrorism Act 2005 were likely to be incompatible with the rights to liberty and security ${ }^{118}$ and a fair trial ${ }^{119}$ enshrined in the ECHR. However, the JCHR's recommendations were frequently rejected by the government in favour of those made by Lord Carlile, the Independent Reviewer of Terrorism Legislation. For example, in response to the JCHR's first report on control orders, the then Home Secretary Charles Clarke rejected almost all recommendations, stating: 'In the light of the report produced by Lord Carlile, the independent reviewer of the legislation, on the first nine months of operation of the Act, the Government did not consider that any legislative changes were necessary. ${ }^{\text {'20 }}$ Throughout the remainder of his response, Clarke continued to refer to Carlile's report in opposition to the JCHR's various proposals. For example, with respect to the concern that the control order regime might breach the right to liberty contained within the ECHR, Clarke stated that the government could not:
[A]ccept that any of the control orders that have been made to date impose obligations on individuals that amount to a deprivation of liberty. Lord Carlile makes reference in his report to a number of control orders made in November and December 2005, asserting that such orders could not be more restrictive and remain compatible with the ECHR without a derogation. ${ }^{121}$

He further noted: 'In relation to these control orders, Lord Carlile, who has access to all the material on which the Home Secretary made his decision, says: "They have not been found to amount to the triggering of derogation, indeed there has been no challenge so far on that basis - but the cusp is narrow." Lord Carlile therefore does not conclude that the obligations amount to a deprivation of liberty'. ${ }^{122}$ In response to the JCHR's concerns over issues of procedural fairness in control order proceedings, particularly the use of Special Advocates, Clarke stressed

\footnotetext{
${ }^{117}$ See: Janet Hiebert, 'Parliament and the Human Rights Act: Can the JCHR help facilitate a culture of rights?' (2006) 4(1) International Journal of Constitutional Law 1.

118 Joint Committee on Human Rights, Counter-Terrorism Policy and Human Rights: Draft Prevention of Terrorism Act 2005 (Continuance in force of sections 1 to 9) Order 2006 (2005-06, HL 122, HC 915) 3, 15; Joint Committee on Human Rights, Counter-terrorism Policy and Human Rights: Draft Prevention of Terrorism Act 2005 (Continuance in force of sections 1 to 9) Order 2007 (2006-07, HL 60, HC 365) 3, 9-10; Joint Committee on Human Rights, Counter-Terrorism Policy and Human Rights (Ninth Report): Annual Renewal of Control Orders Legislation 2008 (2007-08, HL 57, HC 356), 8; 14.

119 Joint Committee on Human Rights, Prevention of Terrorism Bill: Preliminary Report (2004-05, HL 61, HC 389) 6; Joint Committee on Human Rights, Counter-Terrorism Policy and Human Rights: Draft Prevention of Terrorism Act 2005 (Continuance in force of sections 1 to 9) Order 2006 (2005-06, HL 122, HC 915) 4, 17-18, 22-23; Joint Committee on Human Rights, Counter-terrorism Policy and Human Rights: Draft Prevention of Terrorism Act 2005 (Continuance in force of sections 1 to 9) Order 2007 (2006-07, HL 60, HC 365) 14; Joint Committee on Human Rights, Counter-Terrorism Policy and Human Rights (Ninth Report): Annual Renewal of Control Orders Legislation 2008 (2007-08, HL 57, HC 356) 16; Joint Committee on Human Rights, CounterTerrorism Policy and Human Rights (Fourteenth Report): Annual Renewal of Control Orders Legislation 2009 (2008-09, HL 37, HC 282) 9; Joint Committee on Human Rights, Counter-Terrorism Policy and Human Rights (Sixteenth Report): Annual Renewal of Control Orders Legislation 2010 (2009-10, HL 64, HC 395) 18, $28-29$.

120 Joint Committee on Human Rights, 'Appendix 1', Counter-Terrorism Policy and Human Rights: Prosecution and Pre-Charge Detention (2005-06, HL 240, HC 1576) 53.

121 Ibid 54.

${ }^{122}$ Ibid.
} 
Carlile's support for the scheme: 'The Special Advocate system has received approval from Lord Carlile ... The Government considers that the Special Advocate procedure accommodates legitimate security concerns whilst also according the individual a substantial amount of procedural justice. ${ }^{123}$ Clarke concluded his letter to the Joint Committee by asserting that: 'The Government maintains that control orders are the best way of addressing the continuing threat posed by suspected terrorists who cannot currently be prosecuted or, in respect of foreign nationals, cannot be removed from the UK. This is a view shared by Lord Carlile. ${ }^{124}$ Clarke's response to the JCHR's first report on the operation of the Prevention of Terrorism Act 2005 set the tone for subsequent Home Secretaries to follow. Lord Carlile's positive reports on the operation of the control order provisions in the Prevention of Terrorism Act 2005 were often cited as the reason not to implement the broader changes recommended by the JCHR. ${ }^{125}$

Even though the JCHR scrutinised anti-terrorism laws for their impact on civil liberties, it did not manage to hold the government to account, because its recommendations were overlooked.

\section{The Establishment and Revision of Key Accountability Institutions}

Review of anti-terrorism legislation appears to have been a key accountability mechanism for the Labour governments elected between 1997 and 2010. The existing annual review of the Prevention of Terrorism (Temporary Provisions) Acts and the Northern Ireland (Emergency Provisions) Acts was transformed into an office of Independent Reviewer of Terrorism Legislation in the first decade of the twenty-first century, as annual review was extended to newly enacted anti-terrorism laws. In the same time period, a new office was established: the Independent Reviewer of the Justice and Security (Northern Ireland) Act 2007. The focus of these reviews was, however, simply on how the laws had been used; they were more a reporting mechanism on the operation of the laws than a means to scrutinise their human rights implications. In this respect then, the Coalition and Conservative governments appear to have departed from Labour, particularly in the (admittedly failed) attempt to establish a Board to review the privacy and civil liberties aspects of anti-terrorism laws. To some extent, the difference can be explained by a change in personnel in the office of the Independent Reviewer under the Coalition government; Lord Carlile retired and was replaced by David Anderson QC, who took a much more expansive view of his mandate to review the UK's anti-terrorism laws and focused not only on use, but also on how the laws affected rights and liberties.

\section{a. Independent Reviewer of Terrorism Legislation}

Despite the existence of an annual reviewer of anti-terrorism legislation since 1984, it was not until 1998 that the provision for some form of post-enactment review of counter-terrorism laws was written into the text of an Act. ${ }^{126}$ The Criminal Justice (Terrorism and Conspiracy) Act 1998, which was enacted in response to the Omagh bombing in August that year, did not require an independent or annual reviewer of the legislation per se, instead, it obliged the Secretary of State to 'lay before both Houses of Parliament at least once in every 12 months a report on the working of this Act.' ${ }^{127}$ The then Home Secretary, Jack Straw, simply chose to continue to lay before parliament the reports of JJ Rowe, the then annual reviewer of the Northern Ireland

\footnotetext{
${ }^{123}$ Ibid 55.

124 Ibid 57.

125 Joint Committee on Human Rights, Government Response to the Committee's Eighth Report of this Session: Counter-Terrorism Policy and Human Rights: Draft Prevention of Terrorism Act 2005 (Continuance in force of sections 1 to 9 order 2007) (2006-07, HL 106, HC 539) 6, 9; HM Government, The Government Reply to the Ninth Report from the Joint Committee on Human Rights Session 2009-10 HL Paper 64 HC 395 (Cm 7856, 2010) 15 .

${ }^{126}$ Criminal Justice (Terrorism and Conspiracy) Act 1998 s 8.

127 Terrorism Act 2000 s 126.
} 
(Emergency Provisions) Acts and the Prevention of Terrorism (Temporary Provisions) Acts, in fulfilment of this new statutory provision. ${ }^{128}$ When the measures contained within the Criminal Justice (Terrorism and Conspiracy) Act 1998 were repealed alongside the other emergency and temporary laws enacted in the twentieth century, the legislation which replaced them, the Terrorism Act 2000, contained the same reporting requirement. ${ }^{129}$ Like Straw before him, the then Home Secretary, David Blunkett, interpreted this review provision as requiring him to lay before parliament a report by a person appointed to conduct an annual review of the legislation. In doing so, he appointed Lord Carlile of Berriew QC to fulfil that role. The appointment was made on the morning of 11 September 2001, shortly before the terrorist attacks on the United States. ${ }^{130}$ With that appointment, the contemporary office of the Independent Reviewer of Terrorism Legislation began to evolve. ${ }^{131}$

Despite the permanence of the Terrorism Act 2000, compared to the temporary nature of the earlier laws, Lord Carlile was provided the same terms of reference as his predecessor, JJ Rowe, who inherited the terms of reference from the first annual reviewer, Sir Cyril Philips, appointed in 1984. In his first report on the Terrorism Act 2000, Lord Carlile stated:

My purpose and the requirement of this report are to assist the Secretary of State and Parliament in relation to the working of the Terrorism Act 2000 ... the terms of reference may be found in the letters of appointment to my predecessors and myself. They are to be found too in the Official Report of the House of Lords debate of the $8^{\text {th }}$ March 1984, which shows clearly what Parliament intended when the post of reviewer was first established: the Reviewer should make detailed enquiries of people who use the Act, or are affected by it, and the Reviewer may see sensitive material. ${ }^{132}$

There was no mention of whether the review should include a consideration of the impact of the legislation on civil liberties, and Lord Carlile did not himself adopt a wider interpretation of his terms of reference to conduct the review on those grounds. However, the role of the Independent Reviewer did not stand still during the first decade of the twenty-first century; it evolved in line with the enactment of various new anti-terrorism laws in response to terrorist attacks both at home and abroad. Review clauses were inserted into a number of these laws, including Part 4 of the Anti-Terrorism, Crime and Security Act 2001, which provided for the indefinite detention of non-national terrorist suspects, the Prevention of Terrorism Act 2005, which established the system of control orders, and Part 1 of the Terrorism Act 2006, which created a number of new terrorism offences. ${ }^{133}$ These review clauses were more explicit than the one contained within the Terrorism Act 2000 in that they stated that a person should be appointed to 'review the operation of' the relevant measures. ${ }^{134}$ Lord Carlile was appointed to review those laws, and in doing so, his position became one of 'Independent Reviewer of Terrorism Legislation', rather than simply annual reviewer of the Terrorism Act 2000.

\footnotetext{
${ }^{128}$ See JJ Rowe's letter to Home Secretary Jack Straw at the start of his Report on the Operation in 1999 of the Prevention of Terrorism (Temporary Provisions) Act 1989 (2000).

129 Terrorism Act 2000 s 126.

${ }^{130}$ HC Deb 15 November 2001, vol 374, col 882W.

${ }^{131}$ In his first report on the Terrorism Act 2000, Lord Carlile first refers to himself as the Independent Reviewer: 'In the autumn of 2001 I was appointed as Independent Reviewer of the Terrorism Act 2000'. Lord Carlile, Report on the Operation in 2001 of the Terrorism Act 2000 (2002) 1.

132 Ibid 5.

133 Anti-Terrorism, Crime and Security Act 2001 s 28; Prevention of Terrorism Act 2005 s 14; Terrorism Act 2006 s 36.

${ }^{134}$ See, for example, Anti-Terrorism, Crime and Security Act 2001 s 28(1).
} 
Despite the significant increase in the number of laws subject to review by the Independent Reviewer in the first decade of the twenty-first century, the office remained essentially unchanged. There was no update to the mandate or terms of reference. As such, and for the most part, Lord Carlile reviewed first and foremost the use of the laws, and did not typically reflect upon the implications on human rights and civil liberties of those laws.

\section{b. Independent Reviewer of the Justice and Security (Northern Ireland) Act 2007}

As part of his remit to report on the operation of the Terrorism Act 2000, Lord Carlile also provided separate annual reports on the part of the Act which applied solely to Northern Ireland. Various measures previously contained within the Northern Ireland (Emergency Provisions) Act 1996 were given a five-year temporary lifespan, ${ }^{135}$ during which time it was hoped that violence in Northern Ireland would come to an end as a result of the peace process. When the measures lapsed in 2006, Parliament enacted another temporary law to extend the measures to 31 July 2007. ${ }^{136}$ A year later, they were made permanent in the Justice and Security (Northern Ireland) Act 2007. ${ }^{137}$ In doing so, Parliament also established an annual review of the Act. ${ }^{138}$

The Independent Reviewer of the Justice and Security (Northern Ireland) Act 2007 is appointed to review the operation of sections 21 to 32 of the Act (the permanent powers), as well as 'the procedures adopted by the General Officer Commanding Northern Ireland ... for receiving, investigating and responding to complaints'. ${ }^{139}$ The Independent Reviewer 'shall comply with any request of the Secretary of State to include in a review specified matters'. ${ }^{140}$ The duties and responsibilities of the office have been set out by the current Reviewer, David Seymour:

This is not an inspection, inquiry or investigation but a review of the exercise by the police and military of the use of powers in the JSA. It is concerned with how these exceptional powers are being exercised generally. It is not concerned with individual conduct or complaints which are a matter for the relevant authorities ie the Ombudsman, PSNI disciplinary procedures and the courts. I have no powers to compel people to give evidence or to co-operate. The report depends for its effectiveness on the willingness of many people in Northern Ireland to contribute to the process by talking openly and honestly about the powers, how they are exercised and the impact on their communities ... I am grateful to all of them who spoke openly to me about their experiences of the JSA. This report is based on what they told me. ${ }^{141}$

The main thrust of the Independent Reviewer's work, then, is simply to report on how the legislation has been used in each year. Nothing in the statute requires a review of the civil liberties implications of the measures or their use, and in practice, this has not been carried out by the persons appointed to review the Act. Thus, even though a new accountability institution was established under the Labour government, it was not one which prioritised rights and liberties, merely one that provided statistics on how anti-terrorism legislation had been used.

Conclusion: Trends in the Conservative and Coalition Approach to Counter-Terrorism Review

\footnotetext{
135 Terrorism Act 2000 s 112(4).

136 Terrorism (Northern Ireland) Act 2006 s 1(2).

137 The provisions that allowed for certain terrorism offences in Northern Ireland to be tried without a jury were considered an exceptional departure from the normal criminal justice system and given a renewable two year lifespan. Justice and Security (Northern Ireland) Act 2007 s 9(1).

${ }^{138}$ Ibid s 40.

${ }^{139}$ Ibid s 40(1).

${ }^{140}$ Ibid s 40(3).

${ }^{141}$ David Seymour, Report of the Independent Reviewer Justice and Security (Northern Ireland) Act 2007 Eighth Report: 1 August 2014-31 July 2015 (2016) 5.
} 
Shortly after the Coalition government was elected, it established an internal Home Office review of existing counter-terrorism and security powers, which was backed by independent scrutiny of that review. In doing so, it led to a rebalancing of security and civil liberties, in favour of civil liberties, for the first time in the post-9/11 era. ${ }^{142}$ This was short-lived. Since the emergence of Islamic State, the Coalition and Conservative governments have trodden the same path as the Labour governments that preceded them. They have enacted rights restrictive anti-terrorism laws which significantly impact on the civil liberties of those affected by them. The Coalition and Conservative governments have not taken a radically different path from Labour in terms of approaches to this accountability. Sunset clauses have been used more sparingly, diminishing Parliament's opportunity to scrutinise the legislation. However, even when given the chance under Labour, the focus of most renewal debates was not the substantive content of the laws and their impact on civil liberties, but on the necessity for the laws and the sunset clauses. Conservative scepticism for human rights has played out in its interaction and response to the JCHR, but again, this is not a significant difference from the Labour government, who roundly side lined most of its recommendations. Where the Coalition government did set itself apart from the previous Labour governments was in its attempt to establish a new accountability mechanism - the Independent Privacy and Civil Liberties Board - to review laws specifically for their impact on privacy and civil liberties. The focus on privacy perhaps belies the Conservative perspective of which rights are most worth protecting. The Board was, however, a victim of the 2015 general election and the change to a Conservative, rather than Conservative-led government, and has not actually been established.

Francis Webber's critique of the Conservative government's approach to legal accountability which was highlighted at the start of this article - that it 'is increasingly treating compliance with international legal norms and human rights as optional' - does not play out to the same extent with political accountability. Anti-terrorism laws have often been subject to multiple forms of review and have - to some extent - been scrutinised for their impact on civil liberties. However, political accountability for counter-terrorism does not appear to have been a high priority for the Coalition and Conservative governments, just like the Labour governments that preceded them.

\footnotetext{
${ }^{142}$ This was the first rebalancing of the laws initiated solely by the executive and legislature. A variety of court judgments had previously led to changes in the counter-terrorism regime in favour of rights and liberties. For example, the House of Lords decision in A v Secretary of State for the Home Department [2004] UKHL 56 found the indefinite detention provisions of the Anti-Terrorism, Crime and Security Act 2001 was incompatible with articles 5 and 14 of the ECHR. A number of judgments from 2005 to 2009 led to improvements in the control order regime in favour of the civil liberties of controlees. See, for example: Secretary of State for the Home Department v MB [2007] UKHL 46; Secretary of State for the Home Department v. AF, AM, AN; AE v. Secretary of State for the Home Department, [2008] EWCA Civ 1148; A v United Kingdom (2009) 49 EHRR 29; Secretary of State for the Home Department v AF [2009] UKHL 28.
} 